\title{
SELF-DECEPTION IN FINANCIAL DECISIONS
}

\author{
Marta Maciejasz-Świątkiewicz \\ University of Opole, Opole, Poland \\ e-mail:marta.ms@uni.opole.pl \\ ORCID: 0000-0001-8110-2719
}

\section{Mateusz Musiał}

University of Opole, Opole, Poland

e-mail: mmusial@uni.opole.pl

ORCID: 0000-0001-6705-9750

(C) 2019 Marta Maciejasz-Świątkiewicz, Mateusz Musiał

This is an open access article distributed under the Creative Commons Attribution-NonCommercialNoDerivs license (http://creativecommons.org/licenses/by-nc-nd/3.0/)

DOI: 10.15611/fins.2019.3.03

JEL Classification: G41

\begin{abstract}
Self-deception is classified as the one of the decision-making errors which impede making reasonable decisions. The efficiency of the financial market is associated with the belief that all the participants of the market behave reasonably. They maximise their utility and are able to process all incoming information in the correct way. Considering the fact that financial market anomalies happen, it should be considered that the efficiency of this market is a specific situation in which it may be found. In this work, the research results of the conducted experiment were described. The hypothesis was studied that persons of a higher financial status are more likely to undertake more risky financial decisions which may result in obtaining higher collected financial funds. As a result of the conducted experiment the working hypothesis was confirmed. Due to self-deception consisting in strong identification with the chosen status in the game, strengthened with their own convictions regarding the behaviour of particular professional group representatives, persons with a higher status showed a much greater tendency to risk than persons with a lower status.
\end{abstract}

Keywords: self-deception, financial decisions, behavioural finance.

\section{Introduction}

This work refers to the issue of financial market efficiency, which is related to the belief that market participants behave rationally. They maximise their usability and are able to process all incoming information in the correct way. If financial market efficiency is the axiom (an idea, a statement, that is regarded as being obvious), then there would not be the need to prove its existence. Considering the fact that financial market anomalies happen, it should be considered that the efficiency of this market 
is a specific situation in which it may be found. It can be presumed that the efficiency of a financial market is a dogma (a statement that is regarded as being obvious and true only by the authority of the person who delivers it) pursuant to assertions put forward by some researchers, however only when the research results which indicate the existence of a market anomaly would be ignored. The common misconception about particular phenomenon among individuals is one of the reasons of diagnosing the market anomalies, self-deception being an example of the above.

The purpose of this study is to answer the question of whether self-deception also works in the case of financial behaviour (especially investment behaviour). Within the framework of the conducted experiment, the actual behaviour modes were analysed and due to this fact this study falls into the scope of behavioural finances, in particular experimental. The hypothesis formed before conducting the experiment was that persons of a higher financial status are more likely to undertake more risky financial behaviour which may result in obtaining higher collected financial funds.

\section{Self-deception as a psychological phenomenon}

In the 4th century $\mathrm{BC}$, Demosthenes claimed that: "If we deceive ourselves, we often express in this way what we want to be true. Nothing is easier than self-deceit. For what every man wishes, that he also believes to be true" [Thurman 2008, pp. 25-26]. Self-deception is classified as the one of the decision-making errors which impedes making reasonable decisions. It is sometimes described as self-suggestion.

The essence of self-deception is taking actions (often unconsciously) which are supposed to convince or reassure a person in their preferred conviction (it could be also refraining from action). As Witwicki (1959) argues: "In such cases it is said that something that we tell ourselves, that we play and care about this game, and that we succumb to self-suggestion. In this way, a sick person who eagerly wants to heal, wants to believe and believes that he will recover, and does not allow himself any doubts in this regard. He deliberately does not look at the thermometer, not to know that he had fever again" [Tyszka 2000, p. 190]. Behavioural psychology devotes considerable attention to the self-suggestion phenomenon, because human behaviour is not only affected by external factors. People may affect their own behaviour because Man does not only respond to external factors, but also is able to stimulate himself, making himself independent from the immediate surroundings enough that his behaviour is not any more forecasted on the basis of environment's outside influences [Grün 2008, pp. 44-45].

Hohol described self-deception in the interpersonal recognition as follows: "There are two persons: $\mathrm{A}$ and $\mathrm{B}$ and the statement $p$. To deceive $\mathrm{B}$ about statement $p$, person $\mathrm{A}$ has to be confident that $\sim p$, and at the same time deliberately convince $\mathrm{B}$ that it is $p$. To illustrate self-deception it is assumed that $\mathrm{A}=\mathrm{B}$ " [Hohol]. An example 
of self-deception in interpersonal recognition may be described as follows: there is a statement $p$ "you are sick", person $\mathrm{A}=\mathrm{B}$ convinces and tells him/herself that $\sim p$ which means "person is not sick", whilst in fact $p$ "is sick" and is conscious of that fact.

A classical recognition of self-deception is linked to two paradoxes presented in Figure 1.

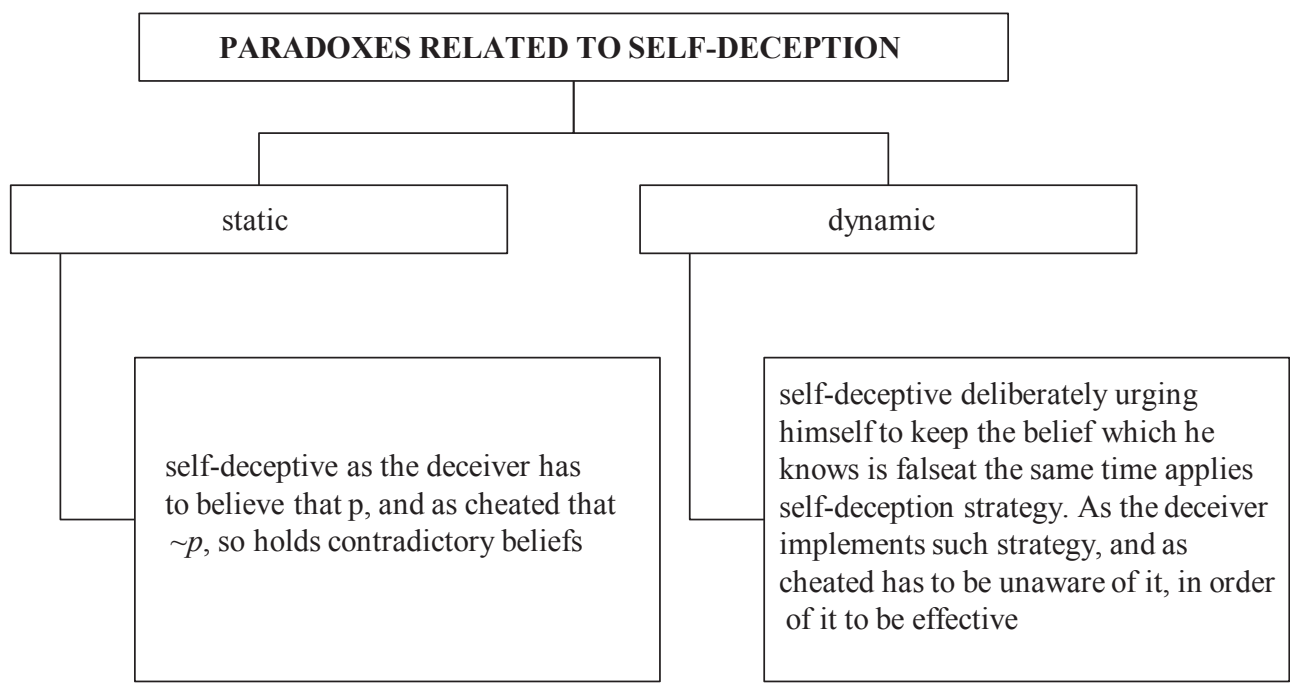

Fig. 1. Paradoxes related to self-deception

Source: on the basis of [Hohol].

In 1984, Quattrone and Tversky researched the self-deception phenomenon and published the results in the "Journal of Personality and Social Psychology". The researchers hired 38 students who were informed that they are participating in the research "psychological and medical aspects in athletics". This study was conducted in several stages:

- Stage I. The participants were asked to dip their hands in cold water and keep them there as long as they could withstand it.

- Stage II. Then the subjects were asked to do a few tasks to make them more reliable. These studies were connected to physical activity such as running, cycling, etc.

- Stage III. The next stage was a short lecture regarding longevity and its relationship to the type of heart. The subjects were informed about two types of heart. Type I is a heart which is associated with health problems, shorter longevity and is more susceptible to disease. Type II is a heart which is associated with a better condition, longer life and is less susceptible to disease. Half of the participants were told that for persons with heart type II, tolerance for cold water 
is increased after an effort, and the other half that it is reduced. They lied to participants to observe whether the participants will be deceiving themselves and think in a self-suggestive way.

- Stage IV. Then the researchers asked participants to dip their hands in cold water [Self-Deception]. Some participants thought that if after this task their pain tolerance induced by cold will be increased, they will learn that they possess the good type of heart, and some that they possess the good type of heart if after the task their pain tolerance will be decreased [Tyszka 2000, p. 190]. The results obtained by Quattrone and Tversky showed that the experimental manipulation was successful. Half of the participants who were informed that after an effort the tolerance for cold water is increased when people possess the II type of heart, were able to keep dipped hands in cold water for a much longer time than the other half during the first attempt. The median result out of the first attempt was 35 seconds, and out of the second over 45 seconds. The other half behaved in the opposite way. The median result of dipping hands in water during the first attempt was around 45 seconds and during the second attempt -10 seconds less.

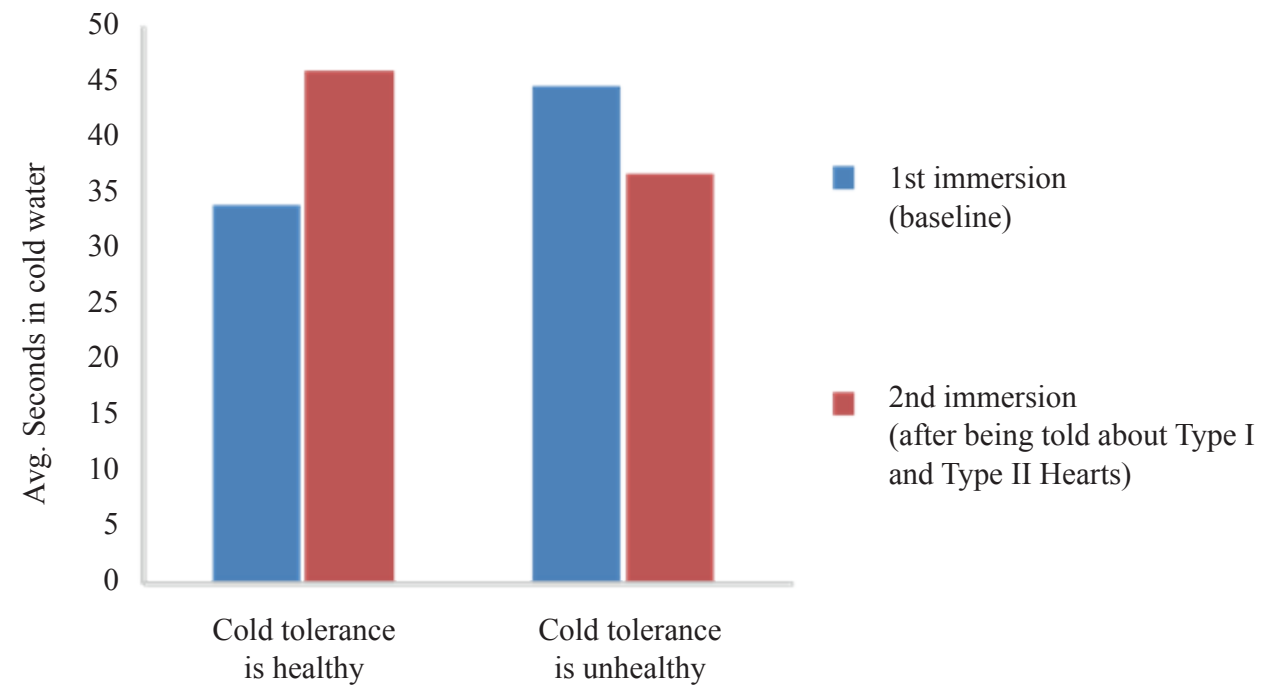

Fig. 2. Time of hand immersion into cold water during attempts I and II

Source: [The Truth...].

- Stage V. In addition to reviewing whether the subjects deceived themselves, they were asked if they deliberately kept their hands in water longer or for less time because it demonstrated their good heart. The response structure to this question is presented in Figure 2. Persons who answered affirmatively to the question said that they felt the water temperature change in the second attempt in comparison 
to the water used during the first attempt. The water temperature was in both attempts the same, of course.

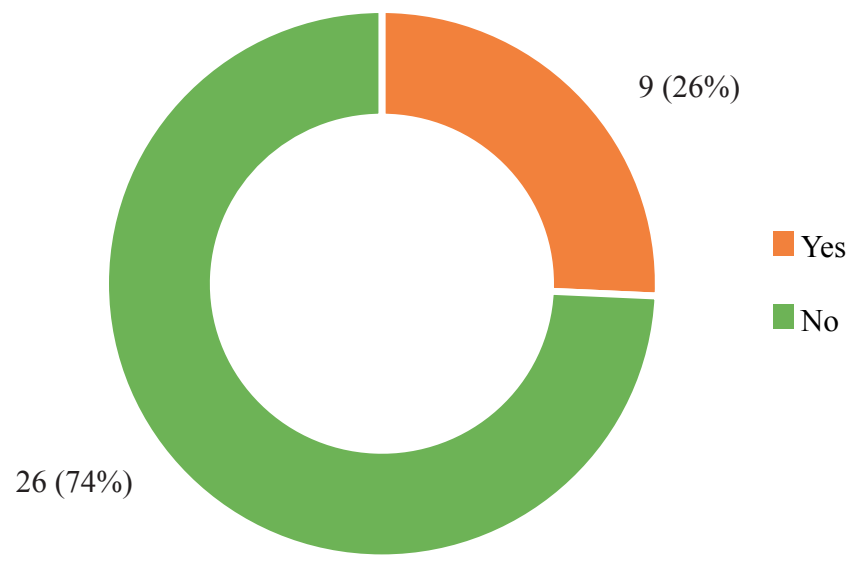

Fig. 3. Response structure to the question: "Did you keep your hands in the water longer or for less time on purpose?"

Source: own work.

Then the participants were asked whether they really believe that they have a healthy heart, where $60 \%$ out of those 29 persons who answered negatively in the previous question replied to this question affirmatively, compared to only $20 \%$ out of 9 persons. Those who denied were able to deceive themselves because they were conscious that the research indeed concerned the medical condition of their heart. Although they did not believe that they have a healthy heart, the research results indicated that they possess heart type II. The researchers deceived the participants by telling them that the time of keeping their hands in cold water reflects their actual state of health. The longer they could do it, the better their health condition was. As a result it enabled the researchers to learn how easily people deceive themselves to achieve the more desired results. The experiment result demonstrates that $71 \%$ of participants showed the ability for self-deception. The experiment indicates different levels of self-deception. The highest level is when people have the tendency for deception and think and act as though their common misconception was true, completely ignoring and discarding the reality [Self-Deception].

As the next experiment demonstrates, the self-deception phenomenon can be found in distorted perception processes, information processing and evaluation in order to protect person against a negative emotions' experience. Pyszczynski, Greenberg, Solomon and Stubing [1993] conducted an experiment during which they asked the subjects to evaluate to what degree they are similar to a person characterized by a particular set of personality features. The following manipulation was made: the subjects were told that the characterized person suffers from cancer. 
In the other case the characterized person's ankle was sprained, for example. The result was clear. The subjects who believed that the characterized person suffers from cancer, assessed their features as completely different from this person. On the other hand, the subjects who were not told about the cancer, did not distance themselves so much [Tyszka 2000, p. 191].

\section{Self-deception examples in financial behaviour}

When analysing self-deception as the decision-making problem, three sources of such behavior may be indicated. First of all it could be the lack of knowledge of their own health condition, finances, wealth, etc. Secondly, the ability for selfdeception, and thirdly - allowing others to deceive [Faber 2006, p. 37]. Various situations may be pointed out, where in practice self-deception appears. One of them is the lack of conviction about the possibility of saving. A person who believes that he/she does not have such a possibility stops from searching for information on saving products because it is not addressed to him/her. On the other hand there are persons who, with an unreasonably optimistic belief, enter into financial commitments being guided by: "It's all going to be OK!". This is the belief that can make a person to fall into a spiral of debt because of their high regard about their own financial competencies. This approach may be associated with the belief that the person will earn more and more, so can afford to make new higher financial commitments. The fact that in every professional career, dismissals or the need to change a job occur is not taken under the consideration. Remuneration does not always have to increase with the further changes of work-places and a developing professional career.

Self-deception is revealed in a situation of future retirement savings. Many young people think that they still have time to save for this purpose. The error consists in the fact that those people believe that in next thirty or forty years they will earn more and have time to start to save for retirement. In fact a similar mechanism works just as with other savings, i.e. the lack of interest in capital accumulation dedicated products. Additionally, if the person believes that since insurance contributions are paid, then it not necessary to save up for retirement on their own. No one knows how will the insurance system look like in following decades, but if we take into consideration the current forecasts, it can be clearly concluded that the retirement benefits will be low. Therefore the belief that there is no necessity of saving for retirement is an attempt of self-deception that a low pension does not concern this particular person.

Self-deception is also when a person, following the suggestions from others and their greed for quick and high profits, decides to engage his/her own assets in risky projects. This person is convinced that since others profit from such an activity, the same will happen in this situation. If, in the beginning, the person succeeds, then he/she acquires the certainty of holding sufficient investor competences. 


\section{Self-deception and the consequences of financial decisions according to own research}

In order to verify whether the self-deception phenomenon occurs in the financial context, an experiment was conducted. Cashflow, a game of Robert Kiyosaki was used [Cashflow 2001]. The time duration was limited to 1.5 hours on purpose, in order to determine the behaviour of aspiring investors and to reduce the impact of the learning process, which is bigger, the longer game lasts. Extending the game's duration would also encourage an increase of experience, sense of certainty and illusion of control [Zielonka 2004, pp. 345-347]. The implemented manipulation concerned an initial profile drawing in the game. The initial profile resulted from the level of remuneration and savings at the beginning of the game. A research question was asked at the beginning concerning whether the initial status remains in connection with the undertaken financing decisions. The related hypothesis was that persons with higher financial status at the beginning of the game will more likely take more risky financial behaviour. Undertaking more risky financial behaviour may result in obtaining higher collected financial funds.

The assessment of the received results was carried out in two ways. The first was to estimate the assets of each participant at the end of the game. The second was self-assessment by answering two questions: "Do you think that your financial status at the beginning of the game was related to decisions that were taken by you?" and "Do you think that if your financial situation at the beginning of the game was different, your decisions would be other than those which You took?". Self-deception consisted in the chosen initial status adoption as the real one, which determines the way of acting and taking financial decisions.

The average amount of savings gathered by the end of the game and their growth in relation to initial value were as follows:

- average amount of savings held at the beginning of the game 506.96 m.u.,

- average amount of savings held at the end of the game 15114.91 m.u.,

- average amount of savings change during the game 14607.96 m.u.

To evaluate the connection between the initial status of the players and the obtained results, correlation indicators were used, see Table 2 .

Table 2. Correlation factors (important with the following)

\begin{tabular}{|l|c|c|c|c|c|}
\hline \multicolumn{2}{|c|}{ Variable } & $x_{1}$ & $x_{2}$ & $x_{3}$ & $x_{4}$ \\
\hline Initial status - payment & $x_{1}$ & 1.0000 & -0.6480 & 0.2069 & 0.2084 \\
\hline Initial savings & $x_{2}$ & -0.6480 & 1.0000 & -0.1987 & -0.2009 \\
\hline Final savings & $x_{3}$ & 0.2069 & -0.1987 & 1.0000 & 1.0000 \\
\hline Savings change & $x_{4}$ & 0.2084 & -0.2009 & 1.0000 & 1.0000 \\
\hline
\end{tabular}

Source: own work based on the conducted research results. 
On the grounds of the values of the correlation indicators, it can be concluded that the correlation between the initial status of the player (categorised by the amount of payment) and the savings amount collected by the end of the game is not present. A relatively high negative relationship occurs between the initial status and the savings amount at the beginning of the game. This is due to the game's objectives which grant a smaller pool of savings for the status characterized by the relatively high payments during the game. On the other hand, in the case of drawing the role of low status, the savings level was relatively higher in comparison to the higher status.

Table 3. Initial status (the amount of payment)

\begin{tabular}{|c|c|c|c|c|}
\hline $\begin{array}{c}\text { The amount } \\
\text { of payment }\end{array}$ & Number of persons & $\begin{array}{c}\text { Number of persons } \\
\text { cumulatively }\end{array}$ & Participation \% & $\begin{array}{c}\text { Participation \% } \\
\text { cumulatively }\end{array}$ \\
\hline 650 & 3 & 3 & 6.5 & 6.5 \\
\hline 720 & 5 & 8 & 10.9 & 17.4 \\
\hline 880 & 7 & 15 & 15.2 & 32.6 \\
\hline 1110 & 4 & 19 & 8.7 & 41.3 \\
\hline 1120 & 8 & 27 & 17.4 & 58.7 \\
\hline 1670 & 5 & 32 & 10.9 & 69.6 \\
\hline 1690 & 4 & 36 & 8.7 & 78.3 \\
\hline 2080 & 1 & 37 & 2.2 & 80.4 \\
\hline 2600 & 4 & 41 & 8.7 & 89.1 \\
\hline 3550 & 5 & 46 & 10.9 & 100.0 \\
\hline
\end{tabular}

Source: own work based on the conducted research results.

Taking into consideration the amount of payments received at the beginning of the game, the subjects were divided in two relatively equal groups to the amount of 1120 m.u. (low status, $N_{1}=27$ ) and above 1120 m.u. (high status, $N_{2}=19$ ). The differences in the results obtained in both groups are presented in the following table.

Table 3. Indicators obtained in game by members of the low and high status groups

\begin{tabular}{|l|c|c|}
\hline \multicolumn{1}{|c|}{ Characteristics } & Low status $\left(N_{1}\right)$ & High status $\left(N_{2}\right)$ \\
\hline Average amount of savings held at the beginning of the game & 582.22 & 400.00 \\
\hline Average amount of savings held at the end of the game & 5520.00 & 28749.79 \\
\hline Maximum savings at the end of the game & 52210.00 & 356880.00 \\
\hline Minimum savings at the end of the game & 100.00 & 930.00 \\
\hline Average increase in savings & $1082 \%$ & $7046 \%$ \\
\hline
\end{tabular}

Source: own work based on the conducted research results.

Analysis of the results obtained by the members of the low and high status groups shows that the highest savings level was accumulated by the group of high status. This was caused particularly by the above-average amount of savings gained by one of the players (356 880 m.u.) compared to the other players in the overall 
population. However, after eliminating an extreme value of savings, the average value of savings gathered by the group with high status amounted to 10520.33 m.u. and still exceeded the average value of savings in the group of low status. Disparities in the savings at the end of the game are also confirmed by the average increase comparison. Just as after the elimination of an extreme value, the average increase of savings is higher in the group of high status and amounts to $2355 \%$.

Low status

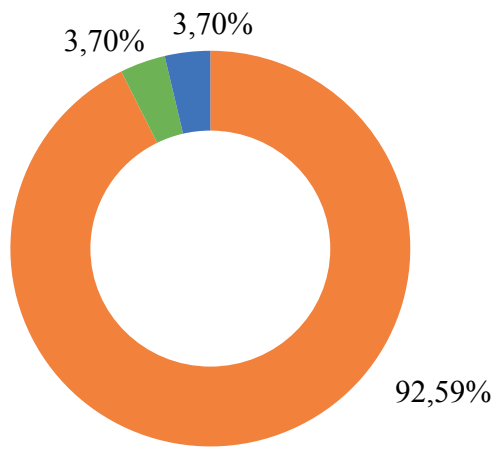

Yes No Nopinion
High status

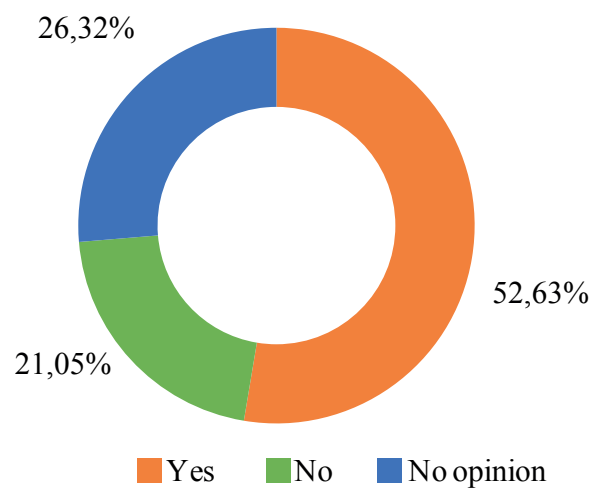

Fig. 4. Response structure to this question: "Did the initial status influenced the decision-making method?"

Source: own work based on the conducted research results.

Low status

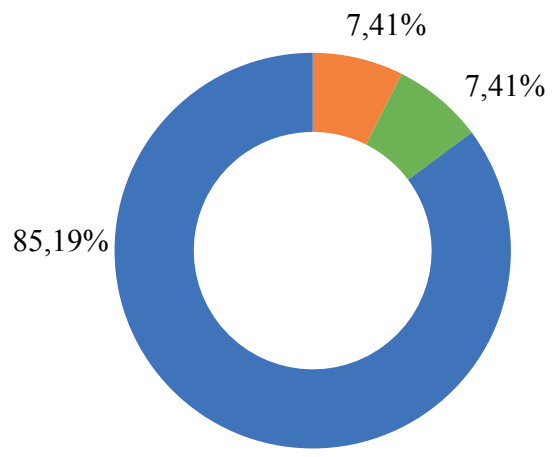

Yes No No opinion
High status

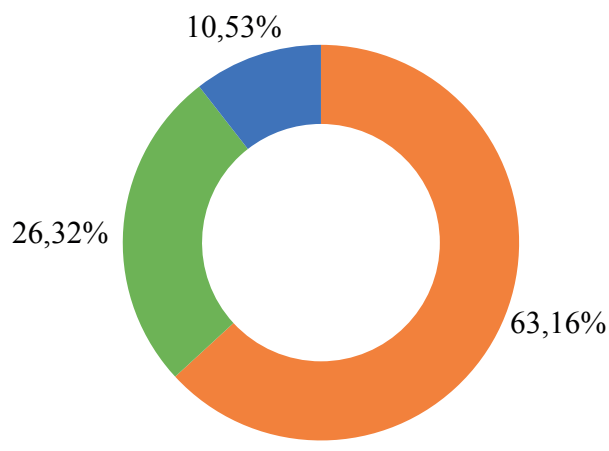

Yes No No opinion

Fig. 5. Response structure to this question: "If the initial status changed, would the decisions be different?"

Source: own work based on the conducted research results. 
Following the end of the game and the description of its results, the experiment's participants were asked two questions. The first concerned an assessment of the impact of the initial status on the way the participants made decisions during the game. The second - the possibility of modification of the decisions taken, if the participants' drawn initial status was different. Figures 4 and 5 present the percentage division of the answers to the first and second question.

The division of the answers to the first question is significantly different for both of the analysed groups. In the group of lower status, the vast majority $(92.59 \%)$ of the participants answered affirmatively to the questions, while in the group of high status only half of the participants answered affirmatively (52.63\%). Other participants gave negative answers $(21.05 \%)$ or could not express their opinion on the matter in question (26.32\%).

The division of the answers to the second question is also significantly different for both the analysed groups. In the group of lower status, the vast majority $(85.19 \%)$ of the participants answered affirmatively to the question, while in the group of high status more than half of the participants answered affirmatively (63.16\%). Other participants gave negative answers $(26.32 \%)$ or could not express their opinion on the matter in question (10.53\%).

The response diversity inside the group of high status and the repeatability of the division of the answers in the group of low status could be explained by the relatively strong identification of the experiment's participants with the professions assigned in the game. Due to the fact that a profession drawn from the pool of high status (e.g. a doctor, a lawyer, a pilot) implied at the same time relatively high continuous incomes in the game, the participants were convinced to some point about their future success in the game. Consequently, in the case of a profession drawn from the pool of low status (e.g. a truck driver, a janitor, a mechanic), their belief in success in the game was relatively low. The satisfaction also was changing - in the case of drawing high status the satisfaction increased, whilst with the low status the satisfaction decreased.

The level of profession identification found confirmation in further behaviour during the game. Definitely more often persons with high status made decisions characterized by a relatively higher risk, whilst those with a low status in the game showed a certain aversion to risk, and simultaneously high tendency to accumulate obtained incomes. This attitude resulted in the fact that the division of the gathered savings by the end of the game was significantly differentiated in both the analysed groups, with a clear predominance of the high status group.

To some extent, strengthening the effect of self-deception among the participants out of the high status group was caused by their own observation and experiences from the real world in the context of human behaviour associated with particular professional groups, which then were transferred directly or indirectly onto their behaviour in the game. 
In the case of persons who were in the group of low status, the self-deception consisted in inhibition or activity limitation in the game because it was believed that they cannot compete with persons of a higher status. In fact the game, by simulating real conditions on the financial market, enables to increase the possessions by incomes' allocation in the offered assets. In this way, income disparities may be changed or removed. It is obvious that persons with a higher income can expand their assets much faster as well as get into financial troubles arising from decision-making errors. A low status does not exclude success in the game, but only causes the adoption of a different strategy.

\section{Conclusions}

It is important to note that the conducted research is not of a representative character. However taking under consideration that this was an experiment, it can be assumed that the number of participants is sufficient to identify a certain tendency. In this experiment, various personal or situational factors could affect the decision-making method, but they are to a large extent outside of the possibility of control possibility. The assumption was that each of the participants playing the game for the first time will be guided by the aspects and rules of this game. In this case it was the initial status determined on the one hand by the amount of the remuneration, and on the other by the savings.

As a result of the conducted experiment the working hypothesis was confirmed. Due to self-deception consisting in the strong identification with the chosen status in the game, strengthened with own convictions regarding the behaviour of the particular professional group representatives, those with a higher status showed a much greater tendency for risk than persons with a lower status. This was reflected in obtaining further assets offered in the game, and in the significant differences in the saving conditions by the end of the game. It appears that the tendency to self-deception goes hand in hand with investors' financial consciousness. The higher the level, the less prone they are to self-deception and more willing to choose risky forms of investing. Therefore it can be concluded that financial education and raising financial awareness is the method to reduce the self-deception tendency in the field of financial behaviour.

\section{References}

Cashflow, 2001, Jak wydostać się z ,wyścigu szczurów”? Zasady gry, Instytut Praktycznej Edukacji. Faber F., 2006, O samozakłamaniu, Duc In Altum, Kraków.

Grün A., 2008, Autosugestia: jak myśleć pozytywnie, Wydawnictwo WAM, Kraków.

Hohol M., Samooszukiwanie - od filozofii do neuronauki, http://mateuszhohol.filozofiawnauce.pl/wp-content/uploads/2013/02/FU_kogni1-11.pdf (21.09.2016). 
Self-Deception, https://explorable.com/self-deception (14.11.2018).

The Truth about Self-Deception, http://www.spring.org.uk/2009/10/the-truth-about-self-deception.php (14.11.2018).

Thurman Ch., 2008, Kłamstwa, w które wierzymy, Wydawnictwo Polskiej Prowincji Dominikanów „W drodze”, Poznań.

Tyszka T., 2000, Psychologiczne pułapki oceniania i podejmowania decyzji, Gdańskie Wydawnictwo Psychologiczne, Gdańsk.

Zielonka P., 2004, Behawioralne aspekty inwestowania na rynku papierów wartościowych, CeDeWu.pl, Warszawa.

\section{SAMOOSZUKIWANIE W DECYZJACH FINANSOWYCH}

Streszczenie: Samooszukiwanie jest klasyfikowane jako jeden z błędów decyzyjnych, utrudniający podejmowanie racjonalnych decyzji. Efektywność rynku finansowego jest zaś związana z przekonaniem, że uczestnicy rynku zachowują się racjonalnie, tj. maksymalizują swoją użyteczność i są w stanie poprawnie przetwarzać wszystkie napływające informacje. Skoro jednak są dowody na to, że anomalie rynku finansowego się zdarzają, należy uznać, że efektywność rynku jest tylko szczególną sytuacją, w jakiej ten rynek może się znaleźć. W artykule opisano wyniki badania przeprowadzonego w formie eksperymentu, podczas którego testowano hipotezę, iż osoby o wyższym statusie finansowym są bardziej skłonne do podejmowania bardziej ryzykownych zachowań finansowych, co może skutkować uzyskiwaniem wyższych kwot zgromadzonych środków finansowych. Przyjętą hipotezę potwierdzono. Wskutek samooszukiwania, polegającego na silnym utożsamianiu się z wylosowanym statusem w grze, osoby o wyższym statusie wykazywały dużo większą skłonność do ryzyka niż osoby o niskim statusie w grze.

Słowa kluczowe: samooszukiwanie, decyzje finansowe, finanse behawiorlane. 